\title{
Konflik dan Negosiasi Ruang Sosial pada Pemodelan Masterplan Desa Wisata
}

\author{
Gregorius Sri Wuryanto $^{\# 1}$, Eka Adhi Wibowo ${ }^{* 2}$ \\ \#Magister Arsitektur, Fakultas Arsitektur Dan Desain, Universitas Kristen Duta Wacana \\ Jl. Dr. Wahidin Sudirohusoda 5-25, Yogyakarta \\ ${ }^{1}$ greg@staff.ukdw.ac.id \\ *Akuntansi, Fakultas Bisnis, Universitas Kristen Duta Wacana \\ Jl. Dr. Wahidin Sudirohusoda 5-25, Yogyakarta \\ 2ekaadhiw@staff.ukdw.ac.id
}

\begin{abstract}
Abstrak - Transformasi desa menjadi sebuah ruang hidup yang berdaya ungkit secara sosial ekonomi melalui kreativitas warganya menjadikan program pemberdayaan desa menemukan pijakan pilihan strategi pembangunan dalam beragam tema. Formasi Desa Wisata menjadi salah satu model mutakhir yang banyak direplikasi baik konsep maupun aktivitas program pemberdayaannya. Kajian pemodelan masterplan Desa Wisata Alam dan Budaya di Dusun Tegal Balong, Desa Bimo Martani, Kapanewon Ngemplak Kabupaten Sleman, Daerah Istimewa Yogyakarta dalam studi kasus tulisan ini akan menyoroti temuan konflik dan negosiasi ruang yang terjadi selama proses penyusunannya. Instrumen analisis kualitatif terhadap proses transformasi ruang sosial melibatkan tiga variabel: (1) peran aktor/agen transformasi; (2) pola produksi dan konsumsi ruang sosial; dan (3) konflik dan negosiasi ruang sosial. Proses desain masterplan yang dilakukan dengan metode partisipatif ini membuka ruang pembelajaran bagi pengembangan kompetensi masyarakat dalam tata kelola inisiatif, manajemen konflik, dan model kerja teamwork yang bersifat kolektif kolegial. Kajian pemodelan masterplan Desa Wisata Alam dan Budaya ini secara kritis akan merekonstruksi ruang sosial sebagai sebuah ruang kreatif komunal bagi pengembangan ekonomi kreatif komunitas desa yang berdaya saing.
\end{abstract}

Kata kunci- ekonomi kreatif desa, konflik dan negosiasi, pemodelan masterplan desa wisata, ruang kreatif, transformasi ruang sosial

Abstract - The transformation of the village into a living habitat which is socio-economically leveraged through the creativity of its citizens makes the village empowerment program find a certain foothold in the various themes of development strategies. The Desa Wisata (Tourism based Village) formation is one of the current models that is widely replicated in both the concept and activities of its empowerment program. The study of modeling the Desa
Wisata Alam dan Budaya (Natural and Cultural based Tourism Village) master plan in Dukuh Tegal Balong, Desa Bimo Martani, Kapanewon Ngemplak, Sleman Regency, Special Region of Yogyakarta in this case study will highlight the findings of conflicts and spatial negotiations that occurred during the designing process. The applied qualitative tools of analysis on the social space transformation processes would involves three variables: (1) the role of the actor/agent of transformation; (2) patterns of production and consumption of social space; and (3) conflict and negotiation of social space. The master plan design process, which was carried out using the participatory method, has opened up a learning space for the development of community competencies in initiatives governance, conflicts management, and collaborative collective teamwork work models. Analytical studies of Masterplan modeling of the Desa Wisata Alam dan Budaya will critically reconstruct the social space as a communal creative space. Hopefully, by this masterplan modelling, it will transform Dusun Tegal Balong into a competitive and creative village .

Keywords - creative economy, spatial conflict and negotiation, masterplan modelling of tourism based village, creative space, social space transformation.

\section{Pendahuluan}

Penyusunan pemodelan masterplan Desa Wisata Alam dan Budaya di Dusun Tegal Balong, Desa Bimo Martani, Ngemplak, Kabupaten Sleman, Daerah Istimewa Yogyakarta ini dilalui dengan beberapa proses interaksi yang menghasilkan dinamika kesepakatan dan ketidaksepakatan. Interaksi sosial di dalam forum diskusi itu sendiri telah memroduksi sebuah ruang sosial baru yang melibatkan penulis sebagai peneliti yang menjadi salah satu 
aktor interaksi pada bentukan ruang sosial baru tersebut. Di dalam konten masterplan Desa Wisata juga terdapat rencana pembuatan ruang-ruang baru secara fisik yang juga diproyeksikan sebagai bentukan ruang-ruang sosial yang tidak saja berupa aktivitas interaksi sosial yang terjadi di dalamnya, tetapi juga bentukan ruang fisik sebagai wadah interaksi sosial tersebut. Tulisan ini sendiri akan mengulas dinamika yang terjadi dari proses transfer pengetahuan dan teknologi terapan kepada penduduk dengan proses aplikasi metode partisipatoris saat menghimpun dan mendengarkan ide-ide orisinal penduduk.

Permasalahan yang dibahas adalah: (1) Bagaimana mengidentifikasi konflik yang terjadi di dalam penerapan metode partisipatoris pada program Pengabdian kepada Masyarakat (PkM) untuk Penyusunan Pemodelan Masterplan Desa Wisata; (2) Bagaimana mengidentifikasi konflik tersebut di dalam substansi masterplan dan metode negosiasi apa yang dilakukan jika terjadi konflik terhadap implementasi konten substansi masterplan; (3) Bagaimana transformasi ruang sosial yang terbentuk ketika konflik dan negosiasi terjadi didalamnya.

Permasalahan di atas dianalisis dengan pendekatan teori terkait dengan produksi ruang sosial (Lefebvre, 2007) yang mengemukakan teorema yang membangun relasi antara produksi ruang dengan interaksi sosial. Lefebvre menyatakan bahwa ruang (sosial) adalah produk (sosial) [1]. Dengan kata lain, ruang sosial sebagai produk dari interaksi dan relasi sosial, telah dibentuk dan dipengaruhi oleh peran orang-orang yang memiliki kontrol atasnya. Habraken (2000) mempertegas relasi kuasa (kontrol) atas ruang ini dapat mewujud secara kongkrit dalam bentuk berupa persepsi terhadap ruang itu sendiri. Dengan persepsi ini orang mampu melakukan intervensi dan perubahan terhadap lingkungan atau tempat dimana dia berdiam/berhuni [2].

Sementara itu, proses transformasi ruang (sosial) secara terstruktur melibatkan analisis terhadap lima variabel, yaitu: (1) keteraturan keruangan (spatial order); (2) aktor (agents); (3) produksi dan konsumsi ruang (sosial); (4) konflik dan negosiasi ruang; (5) kontinuitas dan diskontinuitas [3]. Dari kelima variabel tersebut, kajian ini berfokus kepada tiga variabel saja, yaitu: (1) peran aktor/agen transformasi; (2) pola produksi dan konsumsi ruang sosial; dan (3) konflik dan negosiasi ruang sosial. Variabel keteraturan keruangan dan kontinyuitas/diskontinyuitas tidak disertakan dalam analisis karena keberadaan keduanya tidak signifikan. Faktor yang menyebabkan adalah aspek lokasi pengembnagan masterplan merupakan lahan kosong tanpa bentukan tata ruang eksisting. Sedangkan aspek kontinyuitas/diskontinuitas masih dirasa belum relevan terkait dengan durasi waktu yang belum memungkinkan melihat perubahan yang bersifat kontinyu dalam rentang panjang masa sebelumnya. Penekanan analisis pada peran agen/aktor dalam transformasi ruang sosial difokuskan pada munculnya konflik dan negosiasi yang terjadi saat para aktor memroduksi dan mengonsumsi ruang sosial.

Dalam hal penyusunan masterplan dan tata kelola Desa Wisata Alam dan Budaya Tuk Bulus, Dusun Tegal Balong ini, melalui observasi yang dilakukan peneliti telah menunjukkan bahwa masyarakat daerah tersebut memiliki sifat patembayan atau paguyuban, dimana rasa kekeluargaan dan kegotongroyongan masih sangat tertanam dalam interaksi dan perilaku. Ini merupakan modal sosial yang sangat kokoh untuk menandai kearifan lokal yang masih hadir atau dihadirkan dalam tata kelola desa wisata yang akan dibentuk.

Menurut Soetomo (2009), masyarakat adalah suatu kesatuan yang selalu berubah dan hidup karena proses masyarakat. Masyarakat terbentuk melalui hasil interaksi yang terus-menerus antar-individu. Dalam kehidupan bermasyarakat selalu ditemui kehidupan individu dengan masyarakat yang saling memengaruhi. Salah satu faktor yang dapat menimbulkan perubahan adalah pendidikan atau edukasi [4].

Mubarak dan Chayatin (2009) menyatakan bahwa edukasi adalah proses perubahan perilaku yang dinamis, dimana perubahan tidak hanya dari segi teori dan prosedur dari orang ke orang lain, melainkan juga perubahan terjadi karena menimbulkan kesadaran dari dalam individu, kelompok, atau masyarakat itu sendiri [5]. Aspek edukasi ini menjadi salah satu bentuk intervensi penulis (selaku tim PkM) terhadap formasi kompetensi warga bagi terwujudnya tata kelola dan aktivasi desa wisata. Sebuah intervensi peran yang secara kongkrit akan diwujudkan pada proses peningkatan kesadaran warga untuk membentuk badan hukum usaha yang sesuai dengan karakter kegotongroyongan dan kekeluargaan, yaitu koperasi.

Tujuan kajian ditumpukan kepada dua kepentingan, yaitu: (1) bagi masyarakat, kajian ini diharapkan menjadi media edukasi sekaligus metode alih pengetahuan dan teknologi terapan di dalam penyusunan rencana pembangunan dalam sebuah masterplan dan tata kelola program desa wisata dengan badan hukum koperasi yang sekaligus menjadi ruang sosial baru yang lebih kreatif; (2) bagi dunia akademik, kajian ini ditujukan bagi pengenalan proses pembelajaran terstruktur dari aplikasi metode partisipatoris di dalam program penyusunan masterplan dan Koperasi Desa Wisata.

Manfaat kajian diharapkan mampu mendorong tersusunnya sebuah pemodelan masterplan Desa Wisata yang dapat mengakomodasi semua peran dan gagasan dari para pemangku kepentingan yang terlibat aktif sebagai aktor di dalam dinamika konflik dan negosiasi serta sinergi ruang sosial yang terjadi.

\section{METODE PELAKSANAAN}


Metode kajian transformasi ruang sosial berikut fenomena konflik dan negosiasi ruang sosial disesuaikan dengan metode pelaksanaan Pengabdian kepada Masyarakat (PkM) penyusunan pemodelan masterplan desa wisata di Dusun Tegal Balong. Tahapan pelaksanaan kajian yang dilaksanakan secara simultan dengan pelaksanaan PkM meliputi dua klaster tahapan sebagai berikut:

\section{A. Metode Pelaksanaan Penyusunan Pemodelan Master Plan Desa Wisata Alam dan Budaya}

Dalam metode pelaksanaan ini, penyusunan masterplan dilakukan melalui beberapa tahapan, yaitu:

1) Tahap Penjajagan Komitmen Kolaborasi: ini merupakan tahap inisiasi program $\mathrm{PkM}$ yang dimulai dengan adanya permohonan bantuan dari salah satu warga Tegal Balong kepada Tim PkM untuk mendampingi masyarakat dalam menyusun tahapan pengembangan desa wisata. Dalam perkembangan berikutnya Tim PkM dan beberapa anggota Pokdarwis (Kelompok Sadar Wisata) bertemu dan melakukan klarifikasi mengenai motivasi dan kemungkinan peluang kolaborasi sesuai dengan kemampuan masing-masing pihak hingga terbentuknya sebuah komitmen awal. Dalam tahapan ini belum tampak adanya dinamika perbedaan antar warga maupun dengan tim PkM. Pegiat Pokdarwis cenderung menjagai diskusi menjadi perbincangan normatif yang belum berkembang

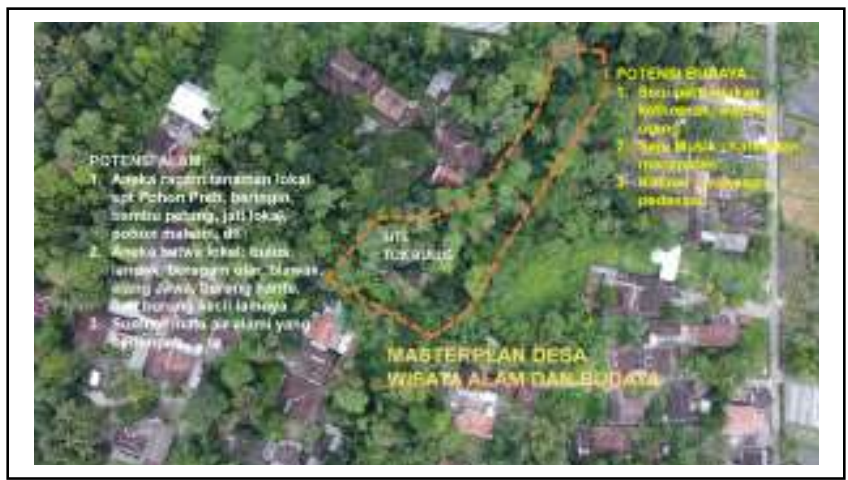

secara berarti.

Gambar 1.Kondisi foto udara site daerah aliran sungai Tuk Bulus di Dusun Tegal Balong yang menjadi lokasi pengembangan fasilitas desa wisata.

2) Tahap Observasi: Dalam tahapan ini dinamika mulai berkembang ketika tim PkM melakukan survey lapangan untuk klarifikasi keinginan warga dengan mengonfirmasi harapan tersebut melalui asesmen potensi dan peluang yang dikonfrontasikan dengan kelemahan dan hambatan teknis di lapangan/site. Metode analisis SWOT (Strengths-Weaknesses-Opportunities-Threats) di lapangan ini selain memunculkan beberapa ekspektasi baru yang berasal dari beberapa ide anggota Pokdarwis juga memunculkan persepsi-persepsi baru yang berasal dari tim PkM. Persepsi ini dilandasi kompetensi teknis yang dimiliki tim PkM dalam menilai adanya kemungkinan-kemungkinan baru ide tentang konsep konservasi alam dan konservasi tradisi/budaya lokal sebagai pengembangan tema desa wisata yang akan dikembangkan. Gagasan semula yang berangkat dari adanya program fasilitasi Dinas Pariwisata Kabupaten Sleman untuk pengembnagan fasilitas sosial yang kemudian diwujudkan oleh penduduk dengan membuat kolam renang. Kolam renang rekreasi ini memanfaatkan sumber daya alam berupa mata air yang berlimpah di dusun tersebut. Dalam perkembangannya fasilitas kolam ini menarik animo masyarakat lokal dan membuat kunjungan dari warga sekitar dusun meningkat. Fenomena inilah yang memunculkan gagasan Pokdarwis untuk mengembangkan desa wisata. Namun ide desa wisata ini masih beroientasi pada penyediaan fasilitas rekreasi berupa kolam dewasa dan kolam renang anak beserta beberapa fasilitas untuk usaha kuliner. Sebuah pengembnagan tema dengan konsep mass tourism ini yang dicoba dipertanyakan Tim PkM dengan beberapa argumentasi terkait dengan kapasitas daya dukung lingkungan, keruskaan yang kemungkinan ditimbulkan, serta peluang tema lainnya yang lebih kaya dan bisa memuliakan beberapa potensi lokal yang ada. Lontaran gagasan ini merupakan dinamika pertama yang memunculkan perbedaan persepsi atas gagasan awal dari sebagian warga yang diwakili oleh 5 anggota/pengurus Pokdarwis.

3) Tahap Dengar Pendapat : perkembangan berikutnya memasuki tahapan konfirmasi kepada warga masyarakat yang lebih luas tentang ekspektasi warga terhadap perkembangan minat masyarakat sekitar untuk berekreasi di kolam renang Tuk Bulus Dusun Tegal Balong ini. Dalam kesempatan dengar pendapat ini pengurus Pokdarwis sekaligus memperkenalkan keberadaan penulis sebagai Tim PkM UKDW yang terlibat dalam program pengembangan fasilitas wisata Tuk Bulus. Disampaikan pula beberapa program yang sudah muncul dari keinginan dan inisiatif warga serta beberapa program dan konsep alternatif lain yang diusulkan oleh tim PkM. Diskusi menjadi menarik, ketika beberapa warga langsung menyatakan setuju dengan beberapa usulan tim PkM. Namun sebagian warga lainnya nampak pasif dalam menanggapinya. Ketika tim PkM menanyakan pendapat kelompok yang pasif ini muncul sebuah realitas sikap yang didasarkan oleh alasan teknis, berupa keraguan atas kemampuan warga untuk menyediakan anggaran. Dari poin inilah diskusi berkembang kepada usulan program berupa penyusunan masterplan dan tata kelola pengembangan desa wisata di Dusun Tegal Balong. Adapun tema konservasi alam dan budaya disetujui warga karena dari diskusi yang ada warga melihat tema tersebut masih bisa tetap mengakomodasi keinginan warga untuk mengembangkan fasilitas kolam renang anak dan usaha kuliner yang sejak semula selalu diangankan warga. Melalui program 
penyusunan pemodelan masterplan ini, tim $\mathrm{PkM}$ sekaligus menyampaikan strategi terkait dengan pengadaan proposal kolaborasi dengan berbagai pihak dalam beberapa skema fasilitasi. Strategi inilah yang kemudian membuat warga menjadi lebih terbuka pada optimisme baru yang melampaui batas persepsi mereka selama ini. Dengan demikian konsekuensi munculnya perspektif baru yang

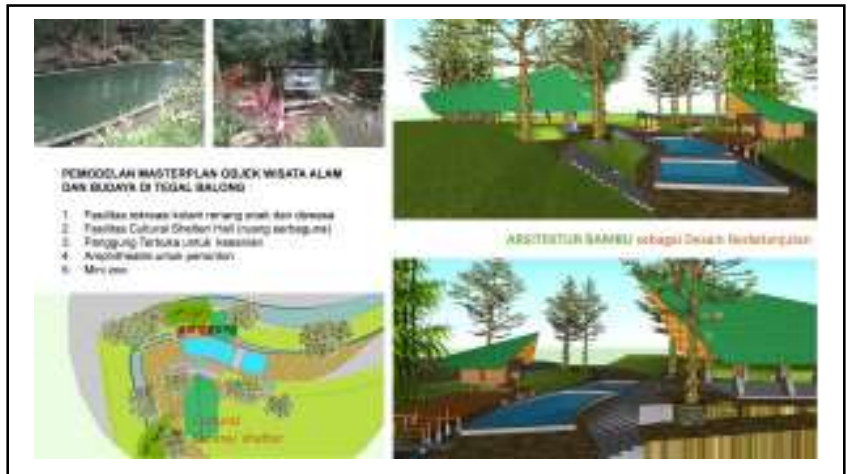

lebih lebar ini mewujud dengan tersusunnya program fungsional fasilitas-fasilitas aktivasi desa wisata yang akan dikembangakan. Dari diskusi dan dengar pendapat tersebut didapat susunan program fungsional yang akan dikembangkan ke dalam masterplan Desa Wisata Alam dan Budaya Tuk Bulus, yaitu: (a) Fasilitas kolam renang anak dan dewasa; (b) fasilitas kuliner; (c) fasilitas pendapa seni dan budaya; (d) fasilitas panggung pertunjukan; (e) mini zoo. Kelima fasilitas desa wisata ini akan dikembangkan di tanah kas desa Bimo Martani yang letaknya di daerah aliran sungai Tuk Bulus.

Gambar 2.Rencana program fungsional fasilitas Desa Wisata Alam dan Budaya Tuk Bulus Tegal Balong dengan desain arsitektur bambu.

4) Tahap Pengembangan Desain : berpijak pada kebutuhan fungsional yang telah disepakati di tahapan sebelumnya, tim PkM memberikan bantuan penyusunan teknis gambar desain arsitektur dan site plan yang meliputi tata kelola lanskap daerah tepian air sungai Tuk Bulus di Dusun Tegal Balong menjadi destinasi wisata alam dan budaya. Dalam tahapan pengembangan desain ini, tim PkM tetap menerapkan metode partisipatoris sebagai pendekatan. Dengan metode ini tim PkM beruisaha tetap mengakomodasi ketrampilan warga dalam tradisi membangun dan ketukangan yang sudah dimiliki. Hal ini untuk membuat warga bisa mengembangkan modal awal berupa ketrampilan lokal yang sangat penting bagi terwujudnya desa wista. Modal budaya berupa ketrampilan ketukangan ini baru disadari warga menjadi sangat penting guna membangun pondasi kepercayaan diri. Metode gotong royong juga diakomodasi sebagai modal sosial yang sangat potensial dan jika dikonversikan secara ekonomi bisa bernilai cukup berarti. Dalam penyusunan desain arsitektur, tim PkM menyampaikan ketentuan teknis bangunan yang berada di area tepian sungai. Mengingat lokasi ini sebenarnya tidak diperkenankan untuk bangunan permanen, maka diusulkan agar fasilitas desa wista ini dikembangkan dengan desain bagunan semi permanen dengan konstruksi knock down yang bisa dibongkar pasang. Pilihan kemudian jatuh pada konstruksi arsitektur bambu dan kayu. Kedua material ini relatif bisa disediakan oleh warga, karena keduanya merupakan material lokal yang juga dimiliki oleh warga.

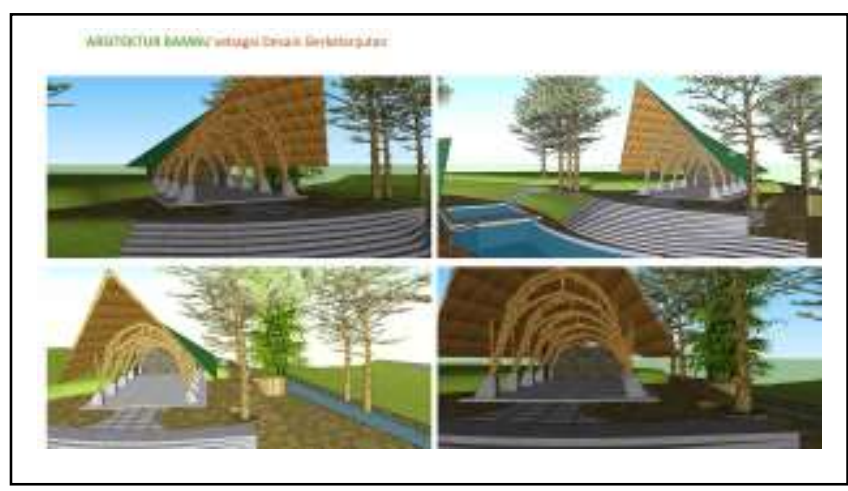

Gambar 3.Rencana desain arsitektur bambu untuk pendapa seni buadaya

5) Tahap Konstruksi : proses konstruksi berlangsung secara bertahap dengan menyesuaikan kemampuan anggaran dari investasi warga maupun skema anggaran dari program fasilitas, baik pemerintah ataupun pihak swasta. Investasi dari pihak korporasi swasta bisa melalui skema dana CSR (Corporate Social Responsibility). Kedua skema tersebut tetap dikelola dengan tidak mengingkari investasi warga sebagai modal utama penyelenggaraan desa wisata ini. Investasi warga diwujudkan dengan modal sosial berupa gotong royong, modal budaya berupa ketrampilan tukang yang dilibatkan dalam proses konstruksi serta modal ekonomi berupa donasi material bangunan, penyediaan konsumsi dan donasi finansial. Dari pihak tim PkM UKDW juga menyumbangkan donasi berupa pelatihan konstruksi bambu dan kayu serta gambar perencanaan/perancangan arsitektur. Dalam tahapan konstruksi ini juga dilakukan transfer pengetahuan dan ketrampilan teknis dari tim PkM kepada warga dusun yang memang berminat memiliki ketrampilan dibidang rancang bangun konstruksi bambu. Metode partisipatoris ini dikembangkan agar dalam program penyusunan masterplan ini dapat berdampak pada peningkatan kompetensi warga. Ini merupakan proses investasi kultural yang diharapakan akan membentuk modal kultural yang baru. Harapoannya dengan modal ketrampilan ketukanagn pada konstruksi bambu ini, masyarakat dapat mengembangkan modal ekonomi bagi dirinya maupun pengembangan desa wisata di masa mendatang. Dinamika yang terjadi pada tahap konstruksi kemungkinan akan terjadi ketika kebiasaan membangun dari pengetahuan tradisi lokal bertemu dengan acuan standar prosedur 
konstruksi yang sesuai dengan peraturan yang ada. Negosiasi yang dilakukan merupakan bagian dari proses edukasi.

6) Tahap Evaluasi dan Monitoring : tahap ini merupakan tahapan yang bisa dilakukan sejak tahapan pertama. Evaluasi dan monitoring menjadi ruang refleksi bagi operasionalisasi konsep dan perencanaan terhadap setiap tahapan kolaborasi. Adapun evaluasi dan monitoring secara umum akan dilakukan bersama warga untuk menilai progres pengembangan desa wisata.

\section{B. Metode Pelaksanaan Perencanaan Pembentukan Koperasi Warga}

Perencanaan pembentukan koperasi menjadi sebuah langkah strategis untuk merintis pengelolaan potensi ruang dan aktivitas sosial budaya warga dusun dengan memanfaatkan berbagai peluang fasilitasi dan kerjasama teknis dengan pihak di luar komunitas dusun terutama kehadiran Peran Dinas Koperasi dan UKM. Adapun tahapan yang dilaksanakan dalam rangka program edukasi warga meliputi tahapan sebagai berikut:

1) Tahap Dengar Pendapat : dalam tahapan ini tim PkM berusaha menggali aspirasi warga di dalam isu terkait dengan tata kelola desa wisata. Pada umumnya warga masih belum pasti di dalam memilih bentuk badan hukum usaha. Sekalipun demikian mereka sadar akan kebutuhan sebuah komunitas yang berbadan hukum. Hal ini dikarenakan pengalaman mereka selama ini mendapatkan program fasilitasi dari pemerintah selalu terdapat skema yang mereka tidak bisa eligible karena belum berbadan hukum. Namun demikian keraguan mereka disebabkan karena kekurangpahaman terhadap badan hukum yang ada. Sehingga keraguan ini masih dianggap wajar. Dan justru mendorong upaya untuk melangkah kepada tahapan yang terkait dengan proses edukasi.

2) Tahap sosialisasi dan edukasi: Tahap ini merupakan tahap edukasi bagi warga agar bisa memahami fungsi dan peran badan hukum dalam pengembangan desa wisata, serta ketepatan di dalam memilih bentuk badan hukum yang sesuai dengan konteks kebutuhan dan karakteristik profil warga. Sejauh analisis yang telah dilakukan oleh tim PkM, maka badan hukum yang tepat bagi warga Dusun Tegal Balomng adalah bentuk koperasi. Dengan demikian pada tahap sosialisasi ini, pendampingan dilakukan oleh Dinas Koperasi dan UKM baik di tingkat Kabupaten Sleman maupunDinas di tingkat Provinsi.

3) Tahap Pendampingan dan Tata Kelola: diharapkan jika masyarakat Dusun Tegal Balong sudah mantap dan memiliki pengetahuan serta ketrampilan teknis di dalam mendirikan dan mengelola koperasi, maka upaya berikutnya adalah mendorong terbentuknya koperasi tersebut. Program pendampingan akan dilakukan dengan pelatihan pembuatan bisnis plan desa wisata serta pelatihan tata kelola cash flow.

\section{PEMBAHASAN}

\section{A. Penyusunan Pemodelan Master Plan Desa Wisata Alam dan Budaya}

Analisis terhadap peran aktor/agen dilakukan di dalam setiap tahapan proses produksi ruang sosial, baik berupa produksi forum diskusi dan interaksi sosial dalam tahapan perencanaan hingga tata kelola desa wisata, maupun ruang sosial yang direncanakan dibangun secara fisik berupa fasilitas aktivasi seni, budaya, rekreasi dan konservasi alam di desa wisata. Kehadiran tim PkM di dalam bentukan ruang sosial baru melalui forum diskusi telah mengimbangi keberadaan dua kelompok aktor lain yang selama ini menjadi agen di dalam ruang sosial yang ada. Jadi analisis konflik dan negosiasi ruang sosial akan dianalisis melalui kajian peran tiga kelompok aktor, yaitu: (a) Warga masyarakat; (b) Pokdarwis; (c) Tim PkM UKDW.

Instrumen analisis yang diaplikasikan dalam kajian ruang sosial ini adalah dengan menggunakan matriks korelasi antara peran aktor - konflik dan negosiasi transformasi ruang sosial. Pada setiap rubrik matriks korelasi diberikan scoring penilaian untuk mengetahui besaran peran dan kontribusi aktor di dalam setiap ruang sosial yang diproduksi.

Adapun scoring untuk klaster rubrik peran aktor dan klaster rubrik konflik sebagai berikut; (a) nilai 1 diberikan pada setiap sikap penolakan atau ketidaksetujuan terhadap sebuah gagasan; (b) nilai 2 diberikan kepada setiap sikap persetujuan; (c) nilai 0 diberikan pada sikap netral terhadap sebuah ide; (d) nilai 3 diberikan pada inisiatif. Sedangkan scoring untuk klaster rubrik negosiasi dan transformasi ruang adalah sebagai berikut: (a) nilai 1 diberikan pada sikap mempertahankan pendapat tanpa kompromi, dan sikap tidak berkenan untuk berubah/bertarnasformasi, (b) nilai 0 untuk setiap sikap skeptis, dan cenderung statis pada upata transformasi, (c) nilai 2 diberikan pada sikap mau bernegosiasi dan terbuka pada proses transformasi.

Instrumen analisis tersebut di atas juga berlaku pada tahapan pembentukan badan hukum usaha (koperasi) yang merupakan instrumen tata kelola desa wisata yang transparan dan akuntabel.

TABEL I

MATRIKS INSTRUMEN ANALISIS

\begin{tabular}{|l|l|l|l|l|l|}
\hline $\begin{array}{l}\text { Ruang } \\
\text { sosial }\end{array}$ & $\begin{array}{l}\text { Peran } \\
\text { aktor }\end{array}$ & Konflik & $\begin{array}{l}\text { Nego- } \\
\text { siasi }\end{array}$ & $\begin{array}{l}\text { Transformasi } \\
\text { Ruang sosial }\end{array}$ & Skor \\
\hline Warga & & & & & \\
\hline Pokdarwis & & & & & \\
\hline Tim PkM & & & & & \\
\hline
\end{tabular}


Pembahasan temuan hasil analisis identifikasi peran aktor dalam setiap tahap produksi ruang sosial akan dibahas di dalam sub-bab III.C.

Dalam kajian mengenai usulan arsitektur dengan konstruksi bambu, tim PkM memberikan ide ini didasarkan pada potensi lokal berupa sumber daya material bambu yang masih cukup tersedia. Di samping itu dengan tipologi konstruksi bambu, upaya untuk melakukan konservasi dan budidaya varietas bambu unggulan di Dusun Tegal Balong menjadi memiliki pijakan konsep yang berkelanjutan. Arsitektur dengan konstruksi bambu telah mengalami perkembangan yang bagus terutama untuk penggunaannya pada bangunan publik [7]. Alasan yang relevan adalah material ini dianggap sebagai material alternatif yang merupakan material ekologis yang dapat diaplikasikan pada konstruksi bangunan [8]. Selain itu sebenarnya material ini memiliki potensi di dalam pengembangan industri kreatif berbasis material alam yang ekologis. Serat bambu misalnya, masih bisa dimanfaatkan secara efektif sebagai material yang bisa menopang industri kreatif masayarakat [9].

Keberadaan bambu petung di Dusun Tegal Balong merupakan bukti bahwa daerah ini merupakan daerah endemik tanaman bambu. Bambu petung sendiri merupakan salah satu varietas unggulan yang sangat bagus digunakan sebagai bahan konstruksi bangunan. Konstruksi bambu dengan beban tarik sangat memungkinkan sebuah inovasi bentuk konstruksi bentang lebar. Tipologi konstruksi dengan bentang lebar ini sangat cocok diaplikasikan pada bangunan pertemuan (hall), seperti pendapa dan temapt aktivitas kreatif yang mampu menampung sejumalh besar orang tanpa terhalang kolom konstruksi yang terlalu rapat.

Secara garis besar, bambu sebagai vegetasi endemik di kepulauan Nusantara belum dimanfaatkan secara optimal. Fakta lain menyebutkan bahwa sampai saat ini tercatat bahwa jumlah varietas yang semula hanya sekitar 65 jenis, saat ini telah berkembang kurang lebih 120 jenis. Dari jumlah ini, 56 jenis diantaranya dapat dimanfaatkan karena memiliki nilai ekonomi (Sutardi, et.al, 2015) [10]. Jika Dusun Tegal Balong memang memiliki minat serisu dalam pengembangan varietas unggul material bambu, maka peluang kekayaan varietas bambu ini bisa dimasukkan sebagai agenda dalam program konservasi sumber daya alam.

\section{B. Pembentukan Koperasi}

Masyarakat di Dusun Tegal Balong merupakan sebentuk paguyuban sosial yang terbentuk secara alami. Situasi tersebut dapat hadir secara kontradiktif. Jika dilihat dari sisi positif, paguyuban ini akan mendorong sebanyak mungkin anggota masyarakat untuk berpartisipasi dalam mengembangkan potensi desanya. Namun dari sisi hubungan kerja, hal tersebut dapat kurang menguntungkan. Hal ini mengingat tata kelola mensyaratkan adanya sistem pengendalian (kontrol) yang belum tentu dapat diterima oleh kerekatan masyarakat komunal yang egaliter. Pengendalian yang bersifat kontrol seoalh memroduksi situasi berjenjang dan berjarak antara peran pengontro dengan yang dikontrol.

Konflik sosial yang terjadi lebih disebabkan belum adanya komunikasi dan sinergi ekspektasi di antara warga terutama terkait dengan pemberdayaan potensi dan pengelolaan aset ruang dan sosial budaya yang ada. Partisipasi warga juga belum secara optimum dikeloala untuk proyeksi pengembangan yang lebih berjangka panjang.

Perencanaan pembentukan koperasi menjadi sebuah langkah strategis untuk merintis pengelolaan potensi ruang dan aktivitas sosial budaya warga dusun dengan memanfaatkan berbagai peluang fasilitasi dan kerjasama teknis dengan pihak di luar komunitas dusun.

Berdasarkan hasil observasi yang dilakukan bentuk usaha Koperasi boleh dikatakan paling sesuai bagi pengembangan bisnis Desa Wisata Tegal Balong. Faktorfaktor yang menjadi pertimbangan, antara lain:

- Masyarakat Tegal Balong lebih bersifat ke arah Paguyuban, yang memiliki dasar kegotongroyongan yang kuat. Prinsip ini sangat sesuai dengan asas Koperasi yaitu kegotong-royongan dan kekeluargaan,

- Sistem kerja Koperasi dapat memberikan deskripsi yang jelas, seperti anggota aktif dan anggota pasif. Pada praktek pengelolaan Desa Wisata Tegal Balong ini, tidak semua masyarakat memiliki waktu yang memadai untuk mengambil bagian dalam pengelolaan desa wisata. Koperasi dapat menjadi sarana bagi masyarakat yang ingin berpartisipasi namun tidak memiliki waktu yang memadai dalam mengelola desa wisata.

Berdasarkan UU no. 25 tahun 1992 tentang Perkoperasian, dijelaskan dalam Pasal 1: Koperasi adalah badan usaha yang beranggotakan orang-seorang atau badan hukum koperasi dengan melandaskan kegiatannya berdasar prinsip koperasi, sekaligus sebagai gerakan ekonomi rakyat atas asas kekeluargaan [6].

Berdasarkan definisi menurut Undang-Undang tersebut koperasi dapat dikatakan sebagai bentuk usaha yang paling sesuai dengan budaya masyarakat Indonesia yang bercorak kekeluargaan. Budaya ekonomi masyarakat memiliki unsur gotong royong yang diwujudkan dalam melakukan kerja sama untuk peningkatan taraf hidup bersama. Bentuk usaha koperasi ini dapat diterapkan dalam bentuk usaha apapun termasuk untuk usaha Desa Wisata yang dikelola secara gotong royong memberdayakan warga setempat dan berpotensi untuk meningkatkan taraf hidup masyarakat di lingkungan tersebut. Dalam konteks ini, pemberdayaan koperasi dan UMKM diarahkan untuk membangun kemandirian dan daya saing melalui penciptaan iklim usaha 
yang kondusif, penerapan iptek, dan penguatan skala ekonomi sehingga memiliki posisi tawar yang tinggi dalam menghadapi kondisi pasar yang dinamis [13].

Selain menjadi badan hukum usaha yang legal, adanya koperasi juga dapat menjadi wadah bagi masyarakat desa wisata untuk menyalurkan potensi-potensi yang dimiliki, karena bentuk usaha desa wisata adalah yang paling banyak melibatkan sumber daya manusia. Secara ekonomi, sektor Pariwisata memberikan kontribusi nyata dalam perolehan devisa negara, pendapatan asli daerah dan juga pendapatan masyarakat yang tercipta dari usaha-usaha kepariwisataan yang dikembangkan. Karakter kepariwisataan yang mampu menciptakan beragam mata rantai kegiatan ekonomi, juga terbukti menciptakan lapangan kerja yang luas dan penyerapan tenaga kerja yang tinggi [12].

Sebagai salah satu sektor pembangunan yang dapat memacu pertumbuhan ekonomi suatu wilayah, pariwisata dianggap sebagai suatu aset yang strategis untuk mendorong pembangunan pada wilayah-wilayah tertentu yang memiliki potensi objek wisata [14]. Dalam pariwisata diperlukan objek wisata baik alam maupun buatan yang dikelola dengan baik dan dibuat semenarik mungkin supaya ada wisatawan yang mau berkunjung. Selanjutnya penyediaan kebutuhan-kebutuhan wisatawan dapat mengikuti antara lain: kuliner, kerajinan cindera mata hingga kesenian yang semaksimal mungkin memberikan kesan yang positif yang menarik calon wisatawan lain untuk datang berkunjung.

Perkembangan wilayah yang memiliki objek wisata dengan tata kelola yang berbasis komunitas biasanya menunjukkan perubahan positif bagi warganya. Sebagai contoh praktik baik adalah Desa Wisata Candirejo yang terletak di kawasan wisata Candi Borobudur Jawa Tengah. Setelah diresmikan menjadi desa wisata pada tahun 2003 berbagai perubahan Desa Candirejo karena pengembangan Desa Wisata Candirejo ini adalah pengembangan pariwisata berbasis komunitas (community based tourism) dimana pengelolaannya langsung oleh masyarakat [11]. Kemandirian masyarakat dalam pengelolaan objek wisata yang menjadi potensi bagi peningkatan kualitas wilayah sebagai sebuah destinasi wisata membutuhkan sistem tata kelola yang akuntabel. Gagasan tentang Koperasi ini menjadi salah satu alternatif bagi pembentukan kemandirian tersebut.

Dalam observasi yang dilakukan di Tegal Balong, tim PkM telah mendapatkan fakta bahwa sebagian pengurus masih belum dapat menerima pendirian koperasi. Sesuatu yang menjadi faktor adalah kentalnya rasa paguyuban, dikuatirkan akan terganggu jika asas profesionalitas dan system tata kelola diterapkan. Hal ini seakan menjadi dilema bagi penulis mengingat tata kelola yang baik diperlukan bagi pengembangan desa wisata. Sebaliknya tanpa tata kelola yang memadai maka keberlanjutan usaha juga bisa terancam dan tujuan usaha tidak tercapai. Upaya yang dijalankan adalah dengan melakukan edukasi yang berkesinambungan bagi masyarakat dan memberikan contoh-contoh bentuk koperasi pengelolaan desa wisata yang berhasil. Edukasi ini tentu memerlukan upaya yang terus menerus, serta soft skill dalam melakukan pendekatan kepada masyarakat untuk dapat menerima sesuatu yang positif bagi kesejahteraan bersama.

\section{Identifikasi Konflik dan Negosiasi}

Dari materi pembahasan di atas, proses identifikasi terhadap konflik dan negosiasi ruang sosial yang terjadi di Dusun Tegal Balong dapat dicermati pada beberapa tabel matriks analisis berikut ini.

TABEL 2

MATRIKS INSTRUMEN ANALISIS KOLAM RENANG

\begin{tabular}{|l|l|l|l|l|l|}
\hline $\begin{array}{l}\text { Kolam } \\
\text { Renang }\end{array}$ & $\begin{array}{l}\text { Peran } \\
\text { aktor }\end{array}$ & Konflik & $\begin{array}{l}\text { Nego- } \\
\text { siasi }\end{array}$ & $\begin{array}{l}\text { Transformasi } \\
\text { Ruang sosial }\end{array}$ & Skor \\
\hline Warga & $\begin{array}{l}\text { Inisi- } \\
\text { ator } \\
\mathrm{s}=3\end{array}$ & $\begin{array}{l}\text { Netral } \\
\mathrm{s}=0\end{array}$ & $\begin{array}{l}\text { Tidak } \\
\text { bisa } \\
\mathrm{s}=1\end{array}$ & $\begin{array}{l}\text { Setuju } \\
\text { transformasi } \\
\mathrm{s}=2\end{array}$ & $\mathbf{6}$ \\
\hline $\begin{array}{l}\text { Pok } \\
\text { darwis }\end{array}$ & $\begin{array}{l}\text { Inisi- } \\
\text { ator } \\
\mathrm{s}=3\end{array}$ & $\begin{array}{l}\text { Netral } \\
\mathrm{s}=0\end{array}$ & $\begin{array}{l}\text { Tidak } \\
\text { bisa } \\
\mathrm{s}=1\end{array}$ & $\begin{array}{l}\text { Setuju } \\
\text { transformasi } \\
\mathrm{s}=2\end{array}$ & $\mathbf{6}$ \\
\hline $\begin{array}{l}\text { Tim } \\
\text { PkM }\end{array}$ & $\begin{array}{l}\text { Setuju } \\
\mathrm{S}=2\end{array}$ & $\begin{array}{l}\text { Netral } \\
\mathrm{s}=0\end{array}$ & $\begin{array}{l}\text { Netral } \\
\mathrm{s}=0\end{array}$ & $\begin{array}{l}\text { Setuju } \\
\text { transformasi } \\
\mathrm{s}=2\end{array}$ & $\mathbf{4}$ \\
\hline
\end{tabular}

Dalam tabel analisis (Tabel 2) di atas tidak terjadi konflik terhadap produksi ruang sosial baru berupa kolam renang (anak-anak). Inisiatif warga dan Pokdarwis sudah sangat solid didukung oleh semua pihak. Peran Tim PkM lebih cenderung untuk kontributif mendampingi keinginan warga masyarakat.

Dalam produksi pendapa kesenian dan budaya (Tabel 3) terdapat inisitaif Pokdarwis untuk memroduksi ruang sosial berupa fasilitas akomodasi untuk gelar budaya dan kesenian warga. Sebuah program aktivasi yang kemudian mendapat pertentangan warga terutama terkait dengan aspek pendanaan. Namun warga terbuka dalam menegosiasikan gagasan ini setelah mendapat masukan dari tim PkM UKDW tentang rencana pembuatan masterplan agar dapat dimanfaatkan sebagai modal dalam mencari mitra strategis untuk pembiayaan program.

TABEL 3

MATRIKS INSTRUMEN ANALISIS PENDAPA

\begin{tabular}{|l|l|l|l|l|l|}
\hline $\begin{array}{l}\text { Pen- } \\
\text { dapa }\end{array}$ & $\begin{array}{l}\text { Peran } \\
\text { aktor }\end{array}$ & Konflik & $\begin{array}{l}\text { Nego- } \\
\text { siasi }\end{array}$ & $\begin{array}{l}\text { Transformasi } \\
\text { Ruang sosial }\end{array}$ & Skor \\
\hline
\end{tabular}




\begin{tabular}{|l|l|l|l|l|l|}
\hline Warga & $\begin{array}{l}\text { Netral } \\
\mathrm{s}=0\end{array}$ & $\begin{array}{l}\text { Aspek } \\
\text { biaya } \\
\mathrm{s}=1\end{array}$ & $\begin{array}{l}\text { Bersedia } \\
\mathrm{s}=2\end{array}$ & $\begin{array}{l}\text { Setuju } \\
\text { transformasi } \\
\mathrm{s}=2\end{array}$ & $\mathbf{5}$ \\
\hline $\begin{array}{l}\text { Pok } \\
\text { darwis }\end{array}$ & $\begin{array}{l}\text { Inisi- } \\
\text { ator } \\
\mathrm{s}=3\end{array}$ & $\begin{array}{l}\text { Netral } \\
\mathrm{s}=0\end{array}$ & $\begin{array}{l}\text { Tidak } \\
\text { bisa } \\
\mathrm{s}=1\end{array}$ & $\begin{array}{l}\text { Setuju } \\
\text { transformasi } \\
\mathrm{s}=2\end{array}$ & $\mathbf{6}$ \\
\hline $\begin{array}{l}\text { Tim } \\
\text { PkM }\end{array}$ & $\begin{array}{l}\text { Setuju } \\
\mathrm{s}=2\end{array}$ & $\begin{array}{l}\text { Netral } \\
\mathrm{s}=0\end{array}$ & $\begin{array}{l}\text { Netral } \\
\mathrm{s}=0\end{array}$ & $\begin{array}{l}\text { Setuju } \\
\text { transformasi } \\
\mathrm{s}=2\end{array}$ & $\mathbf{4}$ \\
\hline
\end{tabular}

Tabel 4 tentang analisis produksi ruang sosial berupa fasilitas kuliner, terdapat situasi yang serupa dengan program pengadaan kolam renang anak-anak. Hal ini dikarenakan memang fasilitas ini sangat dibutuhkan dan diangankan oleh semua warga. Tim PkM tetap berbagi peran untuk mendampingi dan tidak melihat ide ini sebagai sebuah hal yang perlu dikritisi. Namun diskusi yang muncul justru terjadi antar warga. Mereka sepakat untuk mengelola sebaran kiosk dan berusaha menegakkan aturan main dan tata kelola. Karena dikhawatirkan jika fasilitas ini berkembang akan membuka peluang terjadinya konflik kepentingan di antara warga.

TABEL 4

MATRIKS INSTRUMEN ANALISIS FASILITAS KULINER

\begin{tabular}{|l|l|l|l|l|l|}
\hline Kuliner & $\begin{array}{l}\text { Peran } \\
\text { aktor }\end{array}$ & Konflik & $\begin{array}{l}\text { Nego- } \\
\text { siasi }\end{array}$ & $\begin{array}{l}\text { Transformasi } \\
\text { Ruang sosial }\end{array}$ & Skor \\
\hline Warga & $\begin{array}{l}\text { Inisi- } \\
\text { ator } \\
\mathrm{s}=3\end{array}$ & $\begin{array}{l}\text { Netral } \\
\mathrm{s}=0\end{array}$ & $\begin{array}{l}\text { Tidak } \\
\text { bisa } \\
\mathrm{s}=1\end{array}$ & $\begin{array}{l}\text { Setuju } \\
\text { transformasi } \\
\mathrm{s}=2\end{array}$ & $\mathbf{6}$ \\
\hline $\begin{array}{l}\text { Pok } \\
\text { darwis }\end{array}$ & $\begin{array}{l}\text { Inisi- } \\
\text { ator } \\
\mathrm{s}=3\end{array}$ & $\begin{array}{l}\text { Netral } \\
\mathrm{s}=0\end{array}$ & $\begin{array}{l}\text { Tidak } \\
\text { bisa } \\
\mathrm{s}=1\end{array}$ & $\begin{array}{l}\text { Setuju } \\
\text { transformasi } \\
\mathrm{s}=2\end{array}$ & $\mathbf{6}$ \\
\hline $\begin{array}{l}\text { Tim } \\
\text { PkM }\end{array}$ & $\begin{array}{l}\text { Setuju } \\
\mathrm{S}=2\end{array}$ & $\begin{array}{l}\text { Netral } \\
\mathrm{s}=0\end{array}$ & $\begin{array}{l}\text { Netral } \\
\mathrm{s}=0\end{array}$ & $\begin{array}{l}\text { Setuju } \\
\text { transformasi } \\
\mathrm{s}=2\end{array}$ & $\mathbf{4}$ \\
\hline
\end{tabular}

Dalam Tabel 5 terkait dengan produksi amphitheatre dan panggung kesenian, pihak Tim PkM berusaha memertahankan gagasan ide, karena hal ini terkait pada program pemberdayaan ekonomi kreatif yang berbasis pada sub-sektor seni pertunjukkan. Gagasan ini juga berkorelasi dengan konsep desa lestari yang akan didasarkan pada pengembangan desa literasi Basa Jawa sebagai creative engine bagi upaya pelestarian kesenian tradisional seperti kethoparak dan wayang orang. Dengan keberadaan panggung terbuka untuk seni pertunjukan berikut amphitheatre untuk penonton akan melengkapi adanya hall pendapa yang akan memiliki peran serupa sebagai fasilitas indoor.

TABEL 5

MATRIKS INSTRUMEN ANALISIS FASILITAS AMPHITHEATRE DAN PANGGUNG SENI PERTUNJUKKAN

\begin{tabular}{|l|l|l|l|l|l|}
\hline $\begin{array}{l}\text { Am } \\
\text { phi- }\end{array}$ & $\begin{array}{l}\text { Peran } \\
\text { aktor }\end{array}$ & Konflik & $\begin{array}{l}\text { Nego- } \\
\text { siasi }\end{array}$ & $\begin{array}{l}\text { Transfor } \\
\text { masi }\end{array}$ & Skor \\
\hline
\end{tabular}

\begin{tabular}{|l|l|l|l|l|l|}
\hline teater & & & & $\begin{array}{l}\text { Ruang } \\
\text { sosial }\end{array}$ & \\
\hline Warga & $\begin{array}{l}\text { Netral } \\
\mathrm{s}=0\end{array}$ & $\begin{array}{l}\text { Aspek biaya } \\
\mathrm{s}=1\end{array}$ & $\begin{array}{l}\text { Berse- } \\
\text { dia } \\
\mathrm{s}=2\end{array}$ & $\begin{array}{l}\text { Setuju } \\
\text { transfor- } \\
\text { masi } \\
\mathrm{s}=2\end{array}$ & $\mathbf{6}$ \\
\hline $\begin{array}{l}\text { Pok } \\
\text { darwis }\end{array}$ & $\begin{array}{l}\text { Setuju } \\
\mathrm{s}=2\end{array}$ & $\begin{array}{l}\text { Aspek lokasi } \\
\text { dan bentuk }\end{array}$ & $\begin{array}{l}\text { Berse- } \\
\text { dia } \\
\mathrm{s}=2\end{array}$ & $\begin{array}{l}\text { Setuju } \\
\text { transfo- } \\
\text { rmasi } \\
\mathrm{s}=2\end{array}$ & $\mathbf{7}$ \\
\hline $\begin{array}{l}\text { Tim } \\
\text { PkM }\end{array}$ & $\begin{array}{l}\text { Inisi- } \\
\text { ator } \\
\mathrm{s}=3\end{array}$ & $\begin{array}{l}\text { Mempertaha } \\
\text { nkan ide } \\
\mathrm{s}=1\end{array}$ & $\begin{array}{l}\text { Berse- } \\
\text { dia } \\
\mathrm{s}=2\end{array}$ & $\begin{array}{l}\text { Setuju } \\
\text { transfo- } \\
\text { rmasi } \\
\mathrm{s}=2\end{array}$ & $\mathbf{7}$ \\
\hline
\end{tabular}

Konsep konservasi alam yang terwakili dengan program produksi ruang sosial berupa mini zoo untuk menampung koleksi fauna lokal yang memiliki habitat alami di Dusun Tegal balongmendapat sambutan yang luar biasa. Kemungkinan hal ini dikarenakan isu ini bersentuhan dengan faktor kebanggaan dari warga terhadap kekayaan alam yang mereka miliki. Sekalipun gagasan ini di luar dugaan mereka, namun secara antusias mereka mendukungnya. Bahkan ini adalah program yang langsung dieksekusi oleh warga dengan sukarela. Sekalipun tidak berkoordinasi dengan tim PkM mengenai lokasinya, namun insisiasi program ini termasuk yang paling berhasil.

TABEL 5

MATRIKS INSTRUMEN ANALISIS FASILITAS MINI ZOO

\begin{tabular}{|l|l|l|l|l|l|}
\hline $\begin{array}{l}\text { Mini } \\
\text { zoo }\end{array}$ & $\begin{array}{l}\text { Peran } \\
\text { aktor }\end{array}$ & Konflik & $\begin{array}{l}\text { Nego- } \\
\text { siasi }\end{array}$ & $\begin{array}{l}\text { Transfor } \\
\text { masi } \\
\text { Ruang } \\
\text { sosial }\end{array}$ & Skor \\
\hline Warga & $\begin{array}{l}\text { Setuju } \\
\mathrm{s}=2\end{array}$ & $\begin{array}{l}\text { Netral } \\
\mathrm{s}=0\end{array}$ & $\begin{array}{l}\text { Berse- } \\
\text { dia } \\
\mathrm{s}=2\end{array}$ & $\begin{array}{l}\text { Setuju } \\
\text { transfor- } \\
\text { masi } \\
\mathrm{s}=2\end{array}$ & $\mathbf{6}$ \\
\hline $\begin{array}{l}\text { Pok } \\
\text { darwis }\end{array}$ & $\begin{array}{l}\text { Setuju } \\
\mathrm{s}=2\end{array}$ & $\begin{array}{l}\text { Aspek lokasi } \\
\text { dan bentuk }\end{array}$ & $\begin{array}{l}\text { Berse- } \\
\text { dia } \\
\mathrm{s}=2\end{array}$ & $\begin{array}{l}\text { Setuju } \\
\text { transfo- } \\
\text { rmasi } \\
\mathrm{s}=2\end{array}$ & $\mathbf{7}$ \\
\hline $\begin{array}{l}\text { Tim } \\
\text { PkM }\end{array}$ & $\begin{array}{l}\text { Inisi- } \\
\text { ator } \\
\mathrm{s}=3\end{array}$ & $\begin{array}{l}\text { Aspek lokasi } \\
\mathrm{s}=1\end{array}$ & $\begin{array}{l}\text { Berse- } \\
\text { dia } \\
\mathrm{s}=2\end{array}$ & $\begin{array}{l}\text { Setuju } \\
\text { transfo- } \\
\text { rmasi } \\
\mathrm{s}=2\end{array}$ & $\mathbf{7}$ \\
\hline
\end{tabular}

Dalam upaya menjamin terselenggaranya tata kelola aset, potensi, modal serta keterlibatan warga dalam proses perencanaan hingga tata kelola desa wisata sangat diperlukan adanya akuntabilitas yang transparan. Kebutuhan akan sebuah badan hukum usaha untuk penyelenggaraan desa wisata adalah perkara yang sangat urgent dipikirkan warga. Usulan bentuk koperasi didasarkan pada beberapa aspek yang sebagian sudah 
terpenuhi dengan kondisi warga d Dusun Tegal Balong. Hanya kendala keraguan akibat belum adanya pemahaman yang memadai terhadap koperasi serta tata kelolanya membuat ide ini masih mendapat sedikit resistensi dari warga.

TABEL 6

MATRIKS INSTRUMEN ANALISIS PEMBENTUKAN KOPERASI

\begin{tabular}{|l|l|l|l|l|l|}
\hline $\begin{array}{l}\text { Kope } \\
\text { rasi }\end{array}$ & $\begin{array}{l}\text { Peran } \\
\text { aktor }\end{array}$ & Konflik & $\begin{array}{l}\text { Nego- } \\
\text { siasi }\end{array}$ & $\begin{array}{l}\text { Transfor } \\
\text { masi } \\
\text { Ruang } \\
\text { sosial }\end{array}$ & Skor \\
\hline Warga & $\begin{array}{l}\text { Netral } \\
\mathrm{s}=0\end{array}$ & $\begin{array}{l}\text { Netral } \\
\mathrm{s}=0\end{array}$ & $\begin{array}{l}\text { Netral } \\
\mathrm{s}=0\end{array}$ & $\begin{array}{l}\text { Netral } \\
\mathrm{s}=0\end{array}$ & $\mathbf{0}$ \\
\hline $\begin{array}{l}\text { Pok } \\
\text { darwis }\end{array}$ & $\begin{array}{l}\text { Tidak } \\
\text { setuju } \\
\mathrm{s}=1\end{array}$ & $\begin{array}{l}\text { Aspek } \\
\text { pemahaman } \\
\text { dan urgensi } \\
\text { kebutuhan }\end{array}$ & $\begin{array}{l}\text { Berse- } \\
\text { dia } \\
\mathrm{s}=2\end{array}$ & $\begin{array}{l}\text { Setuju } \\
\text { transfo- } \\
\text { rmasi } \\
\mathrm{s}=2\end{array}$ & $\mathbf{6}$ \\
\hline $\begin{array}{l}\text { Tim } \\
\text { PkM }\end{array}$ & $\begin{array}{l}\text { Inisi- } \\
\text { ator } \\
\mathrm{s}=3\end{array}$ & $\begin{array}{l}\text { Aspek } \\
\text { urgensi dan } \\
\text { manajemen } \\
\mathrm{s}=2\end{array}$ & $\begin{array}{l}\text { Berse- } \\
\text { dia } \\
\mathrm{s}=2\end{array}$ & $\begin{array}{l}\text { Setuju } \\
\text { transfo- } \\
\text { rmasi } \\
\mathrm{s}=2\end{array}$ & $\mathbf{7}$ \\
\hline
\end{tabular}

\section{REFLEKSI DAN KESIMPULAN}

Dari hasil pembahasan melalui analisis dengan matriks instrumen dapat direfkesikan mengenai kontribusi peran aktor di dalam produksi ruang sosial dengan skoring 28 untuk Warga; 38 untuk Pokdarwis; dan 37 untuk Tim PkM. Dari hasil skoring ini dapat dilihat bahwa Pokdarwis masih memegang peran yang cukup signifikan dengan skor tertinggi, hanya berbeda satu poin dengan tim PkM. Skor tim PkM termasuk tinggi dikarenakan fungsi kontribusi ide yang cukup menonjol. Sebagi sebuah upaya merangsang kontribusi warga, inisiasi dan pengembangan ide dari warga dirasakan perlu membutuhkan dukungan ide-ide teknis dari kepakaran. Proses negosiasi ide tim PkM terhadap interpretasi dan persepsi masyarakat terhadapnya merupakan proses dialogis yang menjadi bagian dari tahap edukasi.Warga secara aktif telah memberikan pendapat dan reaksi terhadap gagasan yang dimunculkan dalam forum diskusi. Hal ini menandakan kolaborasi aktif telah dilakukan oleh warga, baik secara langsung maupun melalui Pokdarwis. Kecilnya skor pada nilai konflik menandakan memang warga masih segan dengan konflik. Mereka cenderung bersedia untuk bernegosiasi dan memiliki semangat tinggi untuk bertransformasi. Ini merupakan kabar baik bagi cita-cita terbentuknya desa wisata di Tegal balong. Namun demikian transformasi ruang sosial ini tetap harus diwaspadai terutama pada tata kelola peran dan mekanisme pengambilan keputusan akhir yang harus tetap mengakomodasi gagasan yang solutif, kontributif dan memihak pada konservasi lingkungan.

\section{UCAPAN TERIMA KASIH}

Tim Penulis mengucapkan terima kasih kepada Tim LPPM UKDW, Warga Dusun Tegal Balong, Desa Bima Martani, Ngemplak Sleman, serta Pokdarwis Dusun Tegal Balong, Pihak Pemerintah Daerah di Kabupaten Sleman untuk kolaborasi kreatif yang membuat pelaksanaan Program pengabdian kepada Masyarakat ini dapat dilaksanakan dan terus bisa dilakukan di masa mendatang. Dan tak lupa Tim Penulis juga menyampaikan apresiasi terhadap kerja cerdas Tim Pengelola SENDIMAS yang telah menyediakan forum diskusi ilmiah untuk diseminasi gagasan ini.

\section{DAFTAR PUSTAKA}

[1] N.J. Habraken, The Structure of the Ordinary: Form and Control in the Built Environment. Cambridge, Massachussetts: The MIT Press, 2000

[2] H. Lefebvre, The Production of Space. Translated by Donald Nicholson - Smith. 350 Main Street, Malden, MA 02148-5020, USA: Blackwell Publishing, 2007

[3] G.S.W.P. Utomo, Culture of Dwellings and Production of Space in the Post-Disaster Urban Transformation Processes. (Case Study: Kotagede, Yogyakarta - Indonesia). Dissertation. Unpublished. Fakultät VI - Planen Bauen Umwelt der Technischen Universität Berlin, 2014

[4] Soetomo. Pembangunan Masyarakat "Merangkai Sebuah Kerangka". Yogyakarta : Pustaka Pelajar, 2009

[5] W. I. Mubarak, \& N. Chayatin, Ilmu Keperawatan KomunitasPengantar dan Teori. Jakarta : Salemba Medika, 2009

[6] Undang-Undang No.25 Tahun 1992 Tentang Koperasi

[7] A. Muhsin, "Eksplorasi Bambu pada Bangunan Publik," Prosiding Seminar Nasional ITENAS, p. A-52, 2018

[8] E.Suriani, "Bambu Sebagai Alternatif Penerapan Material Ekologis: Potensi dan Tantangannya," EMARA Indonesian Journal of Architecture, vo.3 no.1, p.34, 2017

[9] D. Nurertamanda, A.Alvin, "Desain Proses Pembentukan Serat Bambu sebagai Bahan Dasar Produk Industri Kreatif Berbahan Dasar Serat pada UKM, “J@ti Undip: Jurnal Teknik Industri, vol.7, no.3, p.139, 2013.

[10] S.R. Sutardi, N. Nadjib, M. Muslich, Jasni, I.M. Sulastiningsih, S. Komaryati, S.Suprapti, Abdurrahman, E. Basri, "Seri Paket Iptek Informasi Sifat Dasar dan Kemungkinan Penggunaan 10 Jenis Bambu" Pusat Penelitian dan Pengembangan Hasil Hutan - Badan Penelitian , Pengembangan dan Inovasi - Kementerian Lingkungan Hidup dan Kehutanan, ISBN: 978-979-3132-60-0, p.11, 2015.

[11] Dwipayana, Ari AAGN, "Pengembangan Desa Wisata Berbasis Community Based Tourism (Studi di Desa Wisata Candirejo Kecamatan Borobudur Kabupaten Magelang Provinsi Jawa Tengah). Thesis Repository Universitas Gadjah Mada, 2013.

[12] Renstra Kemenparekraf 2015-2019. Kemenparekraf 2015

[13] Renstra Kemenkopumkm 2015-2019. Kemenkopumkm 2015

[14] Yakup, AP. "Pengaruh Sektor Pariwisata Terhadap Pertumbuhan Ekonomi Indonesia".Thesis, Universitas Airlangga 2019 